\title{
The Regulation of Ownership of Agricultural Land Rights that Exceeds the Maximum Limit
}

\author{
Ana Rubiyani ${ }^{*}$ and Ahmad Ridwan ${ }^{* *}$ \\ ${ }^{*}$ Student of Master of Law Program, Faculty of Law Universitas Islam Sultan Agung, \\ and National Land Agency Employee, Indonesia, Email: rubiyaniana@gmail.com \\ ${ }^{* *}$ Student of Master of Law Program, Faculty of Law Universitas Islam Sultan Agung \\ email ahmadridwan123@gmail.com
}

\begin{abstract}
Land is a form of gift given by God, but human has given brain to think the challenges of live like the land problems, so that the government tries to regulate it properly. The problems in this thesis are: 1) How to regulate ownership of agricultural land rights that exceeds the maximum limit based on Act No. 56 (Prp) of 1960 concerning the Determination of Agricultural Land Areas? 2) How is the action taken by the Land Office towards ownership of agricultural land rights that exceeds the maximum limit? The method used is juridical empirical, with descriptive analytical specifications. The method used in this research is an empirical juridical approach. The results of this study are: (1) The regulation of ownership of agricultural land rights that exceeds the maximum limit is based on Act No. 56 (Prp) of 1960, namely that the provisions regarding land restrictions state that the application for ownership rights as referred to in Article 4 paragraph 1 of Act No. 56 (Prp) 1960 was limited to a maximum land area of $2000 \mathrm{~m}^{2}$. 2) The steps of the Land Office in implementing Act No. 56 (Prp) of 1960, namely the need for a concept of supervision and control over control of land rights, given the various problems that often arise such as in land registration activities.
\end{abstract}

Keywords: Regulation; Ownership; Agricultural.

\section{INTRODUCTION}

In Act No. 56 (Prp) of 1960 concerning the Stipulation of Agricultural Land Areas ${ }^{1}$ this is one of the Landreform programs in Indonesia. Landreform itself in a narrow sense is an overhaul of land ownership and control as well as legal relationships related to land tenure. Article 12 Act No. 56 Prp of 1960 states that the implementation of restrictions and the amount of land for housing and other developments will be regulated in a government regulation. Elucidation of Article 12 of Act No. 56 Prp of 1960, it can be seen that the regulation of the restriction of agricultural land is more important than residential land and others, because agricultural land involves many people so that it does not contradict Article 17 of the UUPA? .

The main provisions regarding the determination of the maximum limit of land ownership are regulated in Article 17 paragraphs (1) and (2) of the UUPA. Article 17 paragraph (1) of the UUPA determines that by considering the provisions in Article 7, in order to achieve the objectives referred to in Article 2 paragraph (3), the maximum

\footnotetext{
${ }^{1}$ Act No. 56 (Prp) of 1960 concerning the Stipulation of Agricultural Land Areas

${ }^{2}$ Adigita, Monicha R., Ma'ruf, Umar., \& Witasari, Aryani. (2019). The Role and Protection of Laws to Notary Related To the Dispute That Made Between the Parties. JURNAL AKTA: Vol. 6, No. 4, 783-788. Retrieved from http://jurnal.unissula.ac.id/index.php/akta/article/view/7631
} 
and / or minimum area of land that can be owned with any of the rights stated in Article 16 of the UUPA is regulated by individuals or Legal Entity, while Article 17 paragraph (2) UUPA stipulates that the determination of the maximum limit in paragraph (1) of this Article will be carried out by statutory regulations in a short time. The implementation of Article 17 paragraph (2) UUPA is regulated in Act No. 56 / Prp / 1960 concerning the Determination of Agricultural Land Areas.

Land ownership on a large scale that is owned by someone is still a lot happening. For example in the Kendal Regency area of Central Java Province, we have encountered a very large number of lands owned or controlled by one family or even by one person. This situation has a very negative impact on people's lives. Ownership limitations that have been regulated in the law are sometimes overlooked by landowners, given that land has many beneficial potentials such as improving economic life, because agricultural activities can be carried out on the land. This contradicts the Basic Agrarian Law of 1960, which therefore needs to be put in order by the State. The maximum limit of land ownership that has been regulated in the above-mentioned Law is currently not working properly, many factors have occurred so that irregularities in reality often occur. One of the factors causing this to happen is due to the existence of an owner of capital who is able to obtain a large enough land which is done by purchasing with the original community who owns the land. The lack of public knowledge of land regulations is also a factor in this. One of the factors causing this to happen is due to the existence of an owner of capital who is able to obtain a large enough land which is done by purchasing with the original community who owns the land. The lack of public knowledge of land regulations is also a factor in this. One of the factors causing this to happen is due to the existence of an owner of capital who is able to obtain a large enough land which is done by purchasing with the original community who owns the land. The lack of public knowledge of land regulations is a factor in this case ${ }^{3}$.

Policy theory which is an instrument of government, not only in the sense of government which only concerns the State apparatus, but also governance which touches the management of public resources. In essence, policies are decisions or action choices that directly regulate the management and distribution of natural, financial and human resources in the public interest. ${ }^{4}$

\section{METHODS}

The method used in this research is an empirical juridical approach. This empirical juridical research examines the implementation or implementation of Laws and Regulations in lieu of Act No. 56 of 1960 concerning the Determination of Agricultural Land Areas. This research is descriptive analytical, with analytical descriptive research, it can easily find out the problems associated with other related phenomena or symptoms and explain about the implementation of legislation in lieu of Act No. 56 of 1960 on the determination of the area of agricultural land. And the data collected in this study can be classified into two, namely primary data from field research and

3 Ferdiyanti, M. Indah Verena., Purnawan, Amin., \& Soegiyanto. (2019). Setting the Effectiveness of Law Position and Code Notary to the Quality of Performance. JURNAL AKTA: Vol. 6, No. 4, 797-804. Retrieved from http://jurnal.unissula.ac.id/index.php/akta/article/view/7887

${ }^{4}$ Suharto, Edi. (2008). Kebijakan Sosial Sebagai Kebijakan Publik. Bandung: CV Alfabeta, p. 13 
eISSN : 2581-2114, pISSN: 2406-9426

secondary data from literature studies ${ }^{5}$.

\section{RESULTS AND DISCUSSION}

\subsection{Arrangement of Ownership of Agricultural Land Rights that Exceeds the Maximum Limit Based on Act No. 56 (Prp) of 1960 concerning the Determination of Agricultural Land Areas}

The founder of our nation so that regarding the natural wealth of our nation did not escape his attention, we can see this in the contents of our constitution, namely in the body of the 1945 Constitution, namely in article 33 paragraph (3) which reads as follows ${ }^{6}$ :

"The earth, water, and natural resources contained therein, are controlled by the State and used as much as possible for the prosperity of the people."

As a legal basis, the 1945 Constitution $^{7}$ is a source of law. Every law product such as UUPA and government regulations and other provisions under it that implement it must be based on higher regulations which can ultimately be accounted for in the provisions of the 1945 Constitution. The relationship between the 1945 Constitution article 33 paragraph 3 on the maximum limitation of land ownership, in this case agricultural property rights in the UUPA can be seen in article 2 paragraph 3 of the UUPA which explains the authority that comes from the right to control the State. ${ }^{8}$

A development orientation that tends to pursue growth and relies on industrialization strategies, without proper land use planning, results in the conversion of agricultural land for other uses. Even though the shrinkage / narrowing of agricultural land will indirectly increase the number of smallholders. The fact is that government policies that tend to pursue agricultural industrialization but do not pay attention to the structure of land tenure make it more difficult to fulfill the minimum limit of agricultural land ownership. The plantation development program by providing easy licensing for large-scale plantation companies is unconsciously one of the triggers for expelling farmers from their land. ${ }^{9}$

\subsection{Steps that should be taken by the Land Office on Ownership of Agricultural Land Rights that Exceeds the Maximum Limit}

Land policies must be implemented by the Government because of services in the land sector to the community contained in the UUPA which emphasizes that land is a gift from God Almighty to the Indonesian people. Land law policy is part of state policies, as a system of norms for land law policy is not only used to regulate and maintain existing patterns of behavior but more than that. ${ }^{10}$ The National Land Agency as a non-

\footnotetext{
${ }^{5}$ Moleong., Lexy. J. (2005). Metodologi Penelitian Kualitatif Edisi Revisi. Jakarta: PT Remaja Rosdakarya, p. 67-68

${ }^{6}$ Harjanto, Fery., \& Gunarto. (2018). Effects Of Creation Deed of Sale and Purchase of Land Which Does Not Match Procedure of Making Land Deeds. JURNAL AKTA: Vol. 5, No. 4, 857-864. Retrieved from http://jurnal.unissula.ac.id/index.php/akta/article/view/3718

${ }^{7}$ Constitution of 1945

${ }^{8}$ Indonesia, Law on Basic Agrarian Principles, No. 5 of 1960, art. 2.

${ }^{9}$ Alam, Bahrul., \& Khisni, Akhmad. (2020). Legal Protection of Holders of Land Loss Data In The City Land Office of Kendari. JURNAL AKTA: Vol.7, No. 2, 159-164. Retrieved from http://jurnal.unissula.ac.id/index.php/akta/article/view/7963

${ }^{10}$ Widyawati, \& Handoko, Widhi. (2018). The Notary Role / PPAT in Improving Legal Awareness Society to Perform Registration Rights to Land Based on Government Regulation No. 24 of 1997
} 
departmental institution is given the authority to regulate land affairs in Indonesia and is an institution that is authorized to resolve land problems. The National Land Agency policy according to Presidential Regulation Number 10 of 2006 is an agency that is authorized to carry out registration of land rights, establish policies, establish implementing regulations, provide services and supervise and control the implementation of land rights registration. ${ }^{11}$

Article 4 letter $d$ states that, "Welfare of the people, especially through improving the quality of agrarian resources that have arisen so far, can also anticipate potential conflicts in the future in order to ensure the implementation of law enforcement based on the principles as referred to in Article 4 of the MPR Decree". With the hope that the words of conflict will not be heard again, so that the community will be calmer about ownership of their land rights. ${ }^{12}$ In Government Regulation Number 16 of 2004 concerning Land Use ${ }^{13}$, Article 1 sub 2 defines land tenure as the legal relationship between individuals, community groups, or legal entities with the land as referred to in Act No. 5 of 1960 concerning Basic Agrarian Regulations. ${ }^{14}$

Mastery can be used in a physical sense as well as in a juridical sense. There is control on a private aspect and a public aspect ${ }^{15}$. Control in a juridical sense is control based on rights, which is protected by law and generally gives the right holder the authority to physically control the land that is held, for example the land owner uses or takes advantage of the land that is held, not handed over to another party. As for juridical control, even if it gives the authority to control the land that is physically held. The right to control land is a control right based on a right or a power which in fact gives the authority to carry out legal acts as a person who has rights. ${ }^{16}$

Symptoms that arise in land problems are not only due to juridical matters, but develop into multi-sectors (agriculture, industry, transmigration, government, etc.) that use the land, or become multi-dimensional state problems (culture, political, economic, social) so that if it is resolved with the current approach taken by the government, it is not sufficient merely to have a technical juridical nature, but also concern socioeconomic considerations. ${ }^{17}$

on Land Registration. JURNAL AKTA: Vol. 5, No. 4, 975-980. Retrieved from http://jurnal.unissula.ac.id/index.php/akta/article/view/4127

${ }_{11}$ Jaya, Hendro K., \& Purnawan, Amin. (2020). Review Of The Implementation Process Of Completion Of Juridical Code Violations Of Notary In Kendari. JURNAL AKTA: Vol.7, No. 2, 169176. Retrieved from http://jurnal.unissula.ac.id/index.php/akta/article/view/7881

12 Ministry of Agrarian Affairs and Spatial Planning of the National Land Agency, http://kabkendal.atrbpn.go.id/, accessed on 8 May 2020

${ }^{13}$ Government Regulation Number 16 of 2004 concerning Land Use

${ }^{14}$ Act No. 5 of 1960 concerning Basic Agrarian Regulations

${ }^{15}$ Arrohim, Mohammad B., \& Wahyuningsih, Sri Endah. (2020). Analysis of Judicial Application of Criminal Penalty Against Notary / Land Deed Officials Conducting Making Crime of the Fake Authentic Deed in State Court of Semarang. JURNAL AKTA: Vol.7, No. 2, 183-188. Retrieved from http://jurnal.unissula.ac.id/index.php/akta/article/view/7891

${ }^{16}$ Yensih, \& Sukarmi, Hanim, Lathifah. (2019). The Law Strength Of Under Hand Deed That Has Passed By Notary as an Authentic Deed in the Proof of Civil Case in District Court of Cirebon. JURNAL AKTA: Vol. 6, No. 4, 661-668. Retrieved from http://jurnal.unissula.ac.id/index.php/akta/article/view/7596

17 Putra, Axel Budi., \& Maryanto. (2019). Legal Analysis of the Form Deed of Sale and Purchase Agreements and the Disposal of Land Rights as the Basic Right to Apply Broking Which Has 
One of the fundamental problems with land problems and the emergence of symptoms of legal uncertainty in terms of control and exploitation ${ }^{18}$ of land parcels by community members is that registration throughout Indonesia has not been carried out properly, accurately and continuously, including in maintaining registration data. Land registration activities that have not been carried out optimally may result in land rights tenure problems.

Article 27 paragraph (1) states that supervision is carried out by the government by means of supervision and reporting. Supervision is monitoring or monitoring (seeing more of an incident with effort / effort) on the implementation of the plan that has been determined since the beginning, in the process, in achieving the goal until after the incident occurred. Good, effective and efficient supervision must be carried out systematically and measurably. Systematics of supervision will provide optimal results so that activities / businesses achieve their objectives and targets of supervision will provide maximum results.

\section{CLOSING}

\subsection{Conclusion}

The National Land Agency in handling land issues is still passive / waiting for the wishes of the disputing parties, so that it seems less concerned about the interests of the community. To anticipate land problems that are increasingly complex and to minimize land conflicts in the community. The National Land Agency is demanded to be more proactive in resolving land conflicts in accordance with the eleven agendas of the National Land Agency of the Republic of Indonesia.

\subsection{Suggestion}

There is a need for Land Law Reform in Indonesia, from the level of the Central National Land Agency, the Regional Office of the Provincial National Land Agency and City / Regency Land Offices, which until now there are still Land policies that have not regulated the right to ownership of agricultural land that exceeds the limit, given Article 7 of the UUPA.

\section{References}

Journals:

Adigita, Monicha R., Ma'ruf, Umar., \& Witasari, Aryani. (2019). The Role and Protection of Laws to Notary Related To the Dispute That Made Between the Parties. JURNAL AKTA: Vol. 6, No. 4, 783-788. Retrieved from http://jurnal.unissula.ac.id/index.php/akta/article/view/7631

Arrohim, Mohammad B., \& Wahyuningsih, Sri Endah. (2020). Analysis of Judicial Application of Criminal Penalty Against Notary / Land Deed Officials Conducting Making Crime of the Fake Authentic Deed in State Court of Semarang. JURNAL AKTA: Vol.7, No. 2, 183-188. Retrieved from

Expired. JURNAL AKTA: Vol. 6, No. 4, 733-740. Retrieved from http://jurnal.unissula.ac.id/index.php/akta/article/view/7624

${ }^{18}$ Fuditia, Megacaesa., \& Mashdurohatun, Anis. (2020). Protection Against Recipients Notary Deed That Allegedly Protocol To The Legal Issue In Semarang. JURNAL AKTA: Vol.7, No. 2, 177-182. Retrieved from http://jurnal.unissula.ac.id/index.php/akta/article/view/7888 
http://jurnal.unissula.ac.id/index.php/akta/article/view/7891

Ferdiyanti, M. Indah Verena., Purnawan, Amin., \& Soegiyanto. (2019). Setting the Effectiveness of Law Position and Code Notary to the Quality of Performance. JURNAL AKTA: Vol. 6, No. 4, 797-804. Retrieved from http://jurnal.unissula.ac.id/index.php/akta/article/view/7887

Fuditia, Megacaesa., \& Mashdurohatun, Anis. (2020). Protection Against Recipients Notary Deed That Allegedly Protocol To The Legal Issue In Semarang. JURNAL AKTA: Vol.7, No. 2, 177-182. Retrieved from http://jurnal.unissula.ac.id/index.php/akta/article/view/7888

Harjanto, Fery., \& Gunarto. (2018). Effects Of Creation Deed of Sale and Purchase of Land Which Does Not Match Procedure of Making Land Deeds. JURNAL AKTA: Vol. 5, No. 4, 857-864. Retrieved from http://jurnal.unissula.ac.id/index.php/akta/article/view/3718

Widyawati, \& Handoko, Widhi. (2018). The Notary Role / PPAT in Improving Legal Awareness Society to Perform Registration Rights to Land Based on Government Regulation No. 24 of 1997 on Land Registration. JURNAL AKTA: Vol. 5, No. 4, 975-980. Retrieved from http://jurnal.unissula.ac.id/index.php/akta/article/view/4127

Alam, Bahrul., \& Khisni, Akhmad. (2020). Legal Protection of Holders of Land Loss Data In The City Land Office of Kendari. JURNAL AKTA: Vol.7, No. 2, 159-164. Retrieved from http://jurnal.unissula.ac.id/index.php/akta/article/view/7963

Jaya, Hendro K., \& Purnawan, Amin. (2020). Review Of The Implementation Process Of Completion Of Juridical Code Violations Of Notary In Kendari. JURNAL AKTA: Vol.7, No. 2, 169-176. Retrieved from http://jurnal.unissula.ac.id/index.php/akta/article/view/7881

Yensih, \& Sukarmi, Hanim, Lathifah. (2019). The Law Strength Of Under Hand Deed That Has Passed By Notary as an Authentic Deed in the Proof of Civil Case in District Court of Cirebon. JURNAL AKTA: Vol. 6, No. 4, 661-668. Retrieved from http://jurnal.unissula.ac.id/index.php/akta/article/view/7596

Books:

Suharto, Edi. (2008). Kebijakan Sosial Sebagai Kebijakan Publik. Bandung: CV Alfabeta Moleong., Lexy. J. (2005). Metodologi Penelitian Kualitatif Edisi Revisi. Jakarta: PT Remaja Rosdakarya

\section{Regulations:}

Constitution of 1945

Act No. 5 of 1960 concerning Basic Agrarian Regulations

Act No. 56 (Prp) of 1960 concerning the Stipulation of Agricultural Land Areas

Indonesia, Law on Basic Agrarian Principles, No. 5 of 1960, art. 2.

Government Regulation Number 16 of 2004 concerning Land Use

Internet:

Ministry of Agrarian Affairs and Spatial Planning of the National Land Agency, http://kab-kendal.atrbpn.go.id/, accessed on 8 May 2020 